\title{
AGE STRUCTURE OF THE SMOLTS OF THE MIGRATORY MORPHOTYPE OF THE BROWN TROUT (SALMO TRUTTA M. TRUTTA L., 1758) FROM THE GOWIENICA RIVER STRUKTURA WIEKU SMOLTÓW TROCI WĘDROWNEJ (SALMO TRUTTA M. TRUTTA L., 1758) Z RZEKI GOWIENICA
}

\author{
Department of Fisheries Management in Inland Waters, \\ Agricultural University of Szczecin, Poland
}

The present paper shows the age, mean length, and weight of smolts of the migratory morphotype of the brown trout, grown in the drainage area of the Gowienica River (Pomerania). The above parameters are given separately for both sexes and all age groups. Because the scales of the smolts were in the period of annual ring formation, the age determination was preceded by counting the annual rings and analyzing the edge increments. The study was based on a total of 277 smolts acquired in four fishing seasons covering the years of 1980, 1982, 1983, and 1984 .

\section{INTRODUCTION}

The Gowienica is a Pomeranian river. It crosses from east to west the central part of the Szczecin Lowland, emptying to the Stepnica Bay (Fig. 1). The catchment area covers $364,9 \mathrm{~km}^{2}$, and the rivers is $53 \mathrm{~km}$ long (Anonymous 1949).

One of the components of the fish-fauna of the river is the migratory morphotype of the brown trout, Salmo trutta m. trutta L., 1758 (referred later to as "trout"). Its quantities depend in large extent on stocking, initiated in November 1958 by the Polish Angler's Association. The first information on the trout stocking in the drainage area of the Gowienica River was published by Chelkowski (1966). In the following years the trout of the Gowienica River was studied by: Chełkowski (1967), Chełkowski et al. (1994), and Chełkowski and Chełkowska (1995). The first of these papers dealt with the description of the broodstock of the trout of the Gowienica River, the second Fig. 1. Location of the Gowienica River in the Odra River estuary one-with the downstream migration of the 


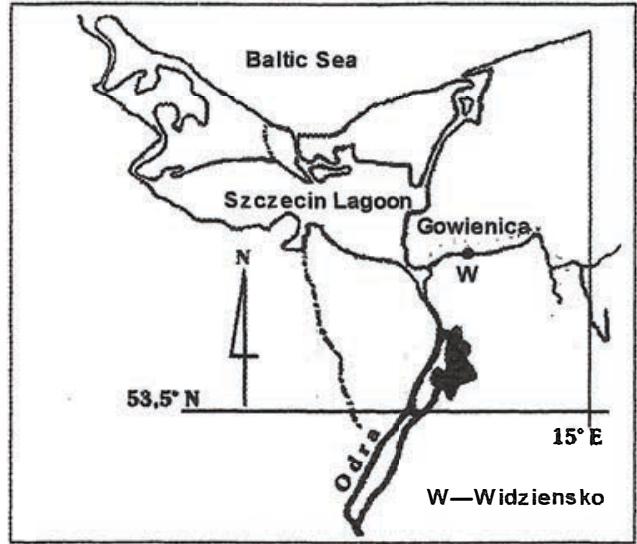

Fig. 1. Location of the Gowienica River in the Odra River estuary

smolts, white the third one-with the biological characteristics of the trout, limited however, to the length and weight.

The age of the trout migrating down the Pomeranian rivers to the Baltic Sea was studied by Chelkowski (1978, 1992, 1995), Chełkowski and Chełkowska (1982), Dębowski and Radtke (1994). There were also publications on the age determination of the trout of Polish rivers based on the scales of adult fish (Chrzan 1959; Chełkowski 1967, 1969, 1974; Domagała 1986).

The present work constitutes a continuation of the studies on the biology of smolts grown in the Gowienica and it was based on the material made available to the present author by the authors mentioned above. The trout smolts were acquired in the fishing seasons covering the years of 1980-1984 and they originated from the stockings conducted within 1977-1983. In the above-mentioned seven years between 130.7 and 239.9 thousand individuals of feeding fry of the migratory trout were stocked yearly (Bartel and Zieliński 1977-1983).

The aims of the present paper were: to determine the age of the smolts based on the scale analysis and to determine mean values of their length and weight in individual agegroups and for each sex. The research material was a total of 287 smolts taken from the Gowienica in four fishing seasons: 1980, 1982, 1983, and 1984.

\section{MATERIAL AND METHODS}

Smolts of the trout were acquired in the course of their downstream migration in the village of Widzieńsko in a distance of $12.6 \mathrm{~km}$ from the place where the river empties to the Szczecin Lagoon (Fig. 1) (Chełkowski and Chełkowska 1995). Sex of the fish was determined through analysis of the gonads using a magnifying glass $(5 \times)$.

In the course of five-year-long catches a total of 2010 trout specimens was collected. A total of 1430 smolts (71.1\%) was subjected to the length analysis. Out of this number a total of 287 fish (Tab. 1) was drown randomly for the age analysis. In the season of 1981 no detail studies were conducted, because of the low number of the fish collected. 
Table 1

Quantitative description of the material studied

\begin{tabular}{|l|l|c|c|c|c|c|}
\hline \multirow{2}{*}{ Season } & \multirow{2}{*}{ Sampling period } & \multirow{5}{|c|}{ No. of fish } \\
\cline { 3 - 7 } & & Acquired & \multicolumn{5}{|c|}{ Subjected to } \\
\cline { 3 - 7 } & & & $\begin{array}{c}\text { Length } \\
\text { analysis }\end{array}$ & $\begin{array}{c}\text { Detailed } \\
\text { analysis }\end{array}$ & $\begin{array}{c}\text { Age deter- } \\
\text { mination }\end{array}$ & $\begin{array}{c}\text { Sex deter- } \\
\text { mination }\end{array}$ \\
\hline 1980 & 08 May-01 Jun & 917 & 917 & 56 & 56 & 53 \\
1981 & 21 Mar-10 Jun & 110 & 69 & - & - & - \\
1982 & 29 Apr-03 Jun & 219 & 183 & 120 & 111 & 27 \\
1983 & 01 Apr-31 May & 355 & 211 & 61 & 60 & 60 \\
1984 & 03 May-18 Jun & 409 & 50 & 50 & 50 & 16 \\
\hline Total & 21 Mar-18 Jun & 2010 & 1430 & 287 & 277 & 156 \\
\hline
\end{tabular}

The scales for further analysis were collected from a place located slightly above the lateral line, between the dorsal fin and the adiposal fin, where-according to Jokiel (1958), Grudniewski (1961) and also Ombredane and Richard (1988) - the scales develop first. Three scales form each fish were examined, following their cleaning and rinsing in a weak solution of ammonia (about 3\%). When the reading was difficult, another sample of scales was taken. Age determination of the smolts was conducted according to Sych (1971), Opuszyński (1979), and Szypuła (1988) on the scale image magnified 47 times obtained form photocopying machine Canon Microprinter 60 (Figs. 2, 3, 4, 5).

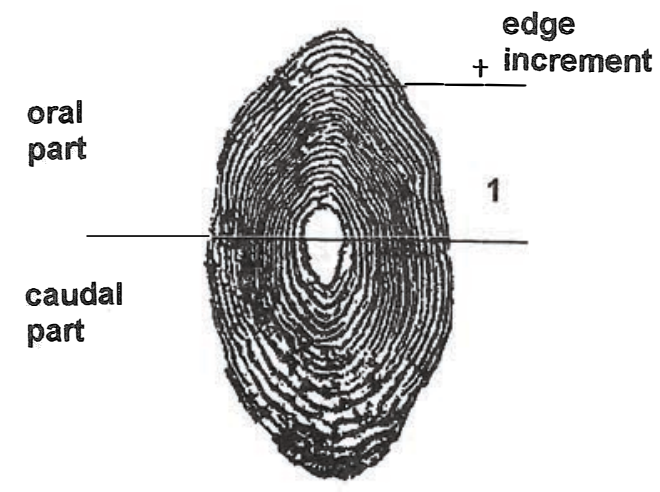

Fig. 2. Scale with one annual ring and "small" edge increment (No. 10/83; fork length $140 \mathrm{~mm}$; weight $23.6 \mathrm{~g}$; scale radii: $\mathrm{S}_{1}=0.53 \mathrm{~mm} ; \mathrm{S}=0.75 \mathrm{~mm}$ ); real age 1 year

Annual ring on the scales can be observed only after establishment of a new annual increment. Because the smolts were in the period of annual ring formation, the determination of their age was preceded by counting the annual rings and analysis of the edge increment. The edge increment is present in all cases and the scale structure is expressed by the formula A+ (Sych 1967b). In the present study the smallest edge increment " $\mathrm{dk}$ " had to contain at least two clearly visible sclerites following the last annual ring. In some fish a newly-formed edge increment was noted on the scales (Figs. 2, 4), while in the others-it,was not present yet (Figs. 3, 5). 


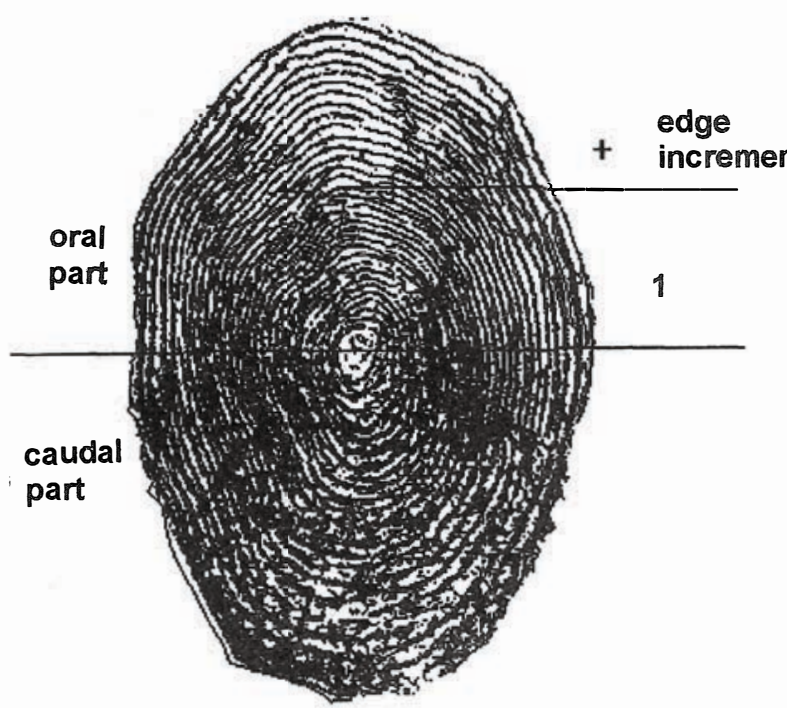

Fig. 3. Scale with one annual ring and "big" edge increment (No. 37/82; fork length $150 \mathrm{~mm}$; weight $33.0 \mathrm{~g}$; scale radii: $S_{1}=0.50 \mathrm{~mm} ; \mathrm{S}=1.00 \mathrm{~mm}$ ); real age 2 years

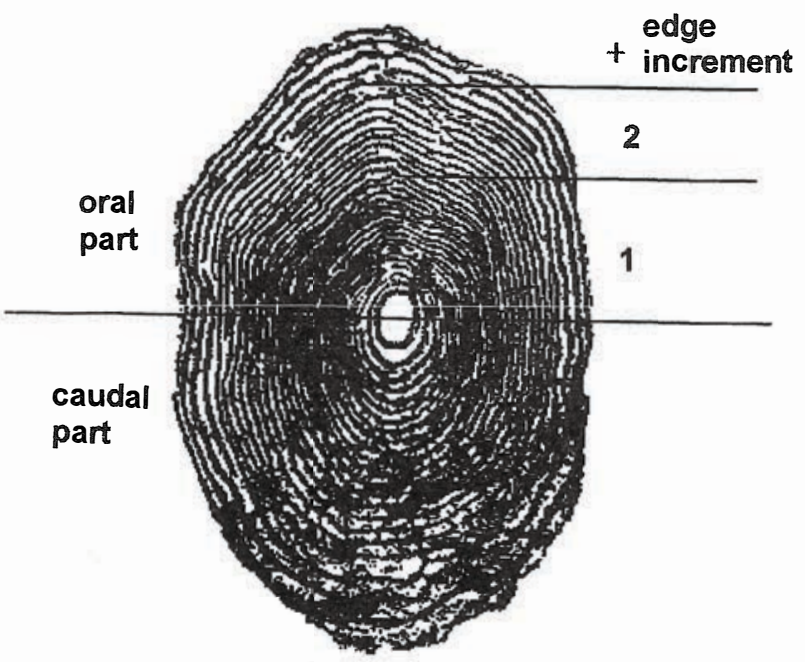

Fig. 4. Scale with two annual rings and "small" edge increment (No. 102/82; fork length $180 \mathrm{~mm}$; weight $54.0 \mathrm{~g}$; scale radii: $\mathrm{S}_{1}=0.41 \mathrm{~mm}$; $\mathrm{S}_{2}=0.85 \mathrm{~mm} ; \mathrm{S}=1.01 \mathrm{~mm}$ ); real age 2 years
In order to differentiate between the newly-formed increment and the last-year's increment, the distribution of the edge increments occurrence was determined for the smolts studied. Following Backiel (1962), Sych (1967b), Chelkowski (1978), and Chełkowski and Chelkowska (1982) — the edge increment was defined as a difference between the length of fish measured after the capture and the fish length determined based on the last annual ring using the back-reading method. In the calculations, the method of Dahl-Lea (Dahl 1910; Lea 1910; Nall 1930; Čugunova 1959; Szypuła 1988) was used for its simplicity.

The oral radius was measured to the nearest $0.01 \mathrm{~mm}$ on the magnified 47 times image of the scale, using a caliper with an electronic digital display. The above-mentioned measurement method is more accurate than that involving a measuring microscope. The calculation of the fish growth rate in the sequential years of life using the method of Dahl-Lea is based on determination of the proportion between the fish body length and the lengtli of the scale radius. Consequently, regardless of the 


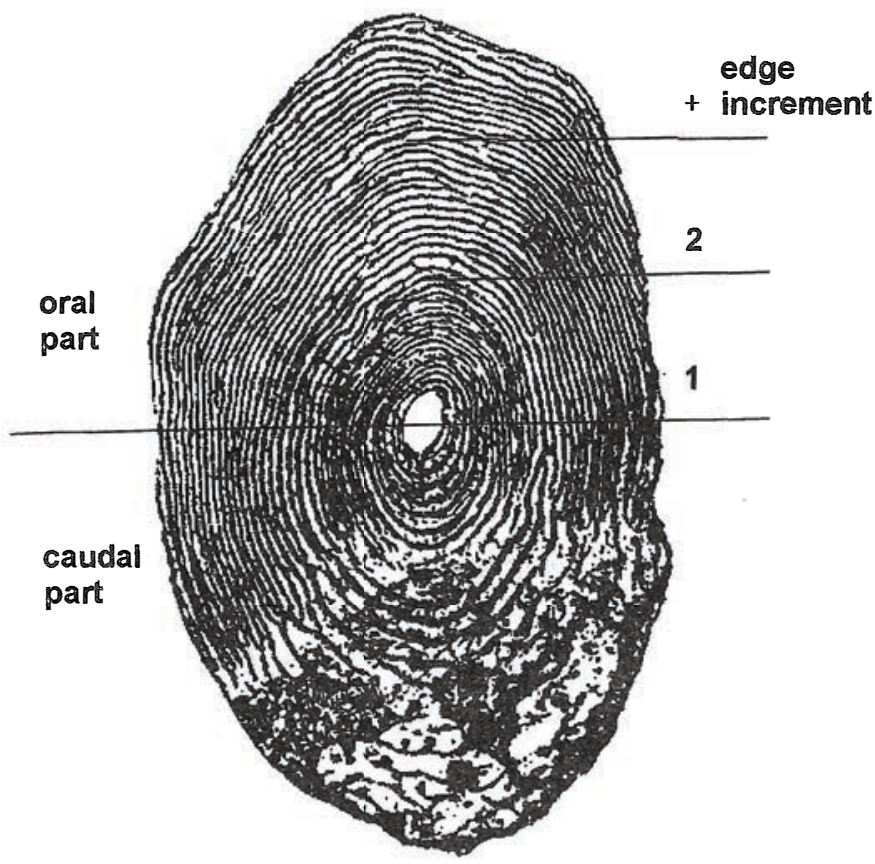

Fig. 5. Scale with two annual rings and "big" edge increment (No. 47/84; fork length $255 \mathrm{~mm}$; weight $136.0 \mathrm{~g}$; scale radii: $\mathrm{S}_{1}=0.41 \mathrm{~mm} ; \mathrm{S}_{2}=0.84 \mathrm{~mm}$; $\mathrm{S}=1.25 \mathrm{~mm}$ ); real age 3 years

magnification of the scale the results of the calculations are the same. The calculated edge increments of the individual fish were arranged in 5-mm groups, separately for $1+$ and $2+$ age-groups, and for fishing seasons-similarly as performed by Sych (1967a, b), Chełkowski (1978), and Chełkowski and Chelkowska (1982) for adult trout and post-smolts. Two-peak arrangement of such curves aided the discrimination according to age-group. Such approach was justified by the observation of the structure of extreme values of: the edge increments " $\mathrm{dk}$ ",

length, and the fish weight. Smolts 1+ with "small" newly-established edge increment were assigned to the group of one-year-old fish, while the smolts of the same group with "big" edge increment were assigned to two-year-old fish. Smolts $2+$ with "small" edge increment were assigned to the group of two-year-old fish while smolts of the same group with "big" edge increment were assigned to three-year-old fish.

Trout smolts of the groups $1+$ and $2+$ with small edge increments had wide edge sclerites (Fig. 2 and 4), while fish with "big" edge increments "dk" had their sclerites of similar width (Figs. 3, 5).

Normal-distribution tests K-S of Lilliefors were conducted using the computer software Statistica 5.0. The tests revealed that all samples-subjected subsequently to the variance analysis for multiple means (Greń 1984)—on the confidence level of 0.05 had a normal distribution. Variance analysis test for multiple means was performed on Statistica 5.0 on the confidence level of 0.05 . The remaining calculations were done using Microsoft Excel 5.0 . 


\section{RESULTS}

The age analysis covered the scales of 287 smolts. Out of this number, the scales of 10 fish (3.5\%), because of undetermined rings or rings with obscure structure (regenerated) were withdrawn. In total the age was determined for 277 fish (Tab. 1).

The calculated values of the edge increments for smolts were grouped in 5-mm classes, separately for ages $1+$ and $2+$ and for 4 fishing seasons, and presented on graphs (Figs. 6, 7, 8, 9). For example the 25-class accommodated smolts with the edge increment between 25 and $29 \mathrm{~mm}$. The data presented (columns) show the number of smolts in individual classes. Two-peak representation of those columns was a reason for separation of those fish for two groups; with "small" and "big" edge increment.

In the fishing season of 1980 there were 44 smolts assigned to group 1+. In this number there were 31 fish (70.5\%) with "small"- and 13 (29.5\%) with "big" edge increment (Fig. 6a). In the same fishing season there were 12 smolts representing group $2+$. In this number were 8 fish (66.7\%) with "small"- and 4 fish (33.3\%) with "big" edge increment (Fig. 6b).

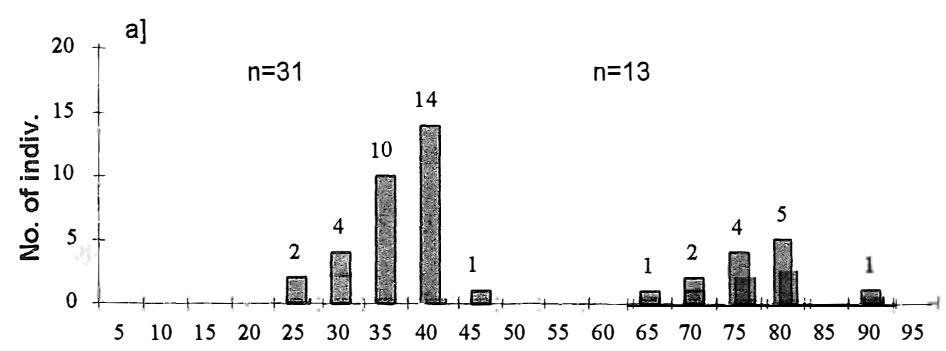

Edge increment [mm]

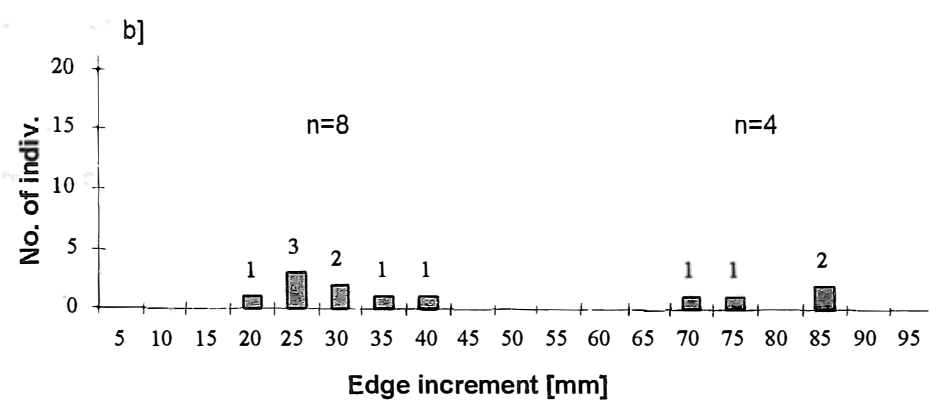

Fig. 6. Distribution of the edge increments of the smolts of the brown trout acquired in the season of 1980 in age groups $1+[\mathrm{a}]$ and $2+[\mathrm{b}]$ 


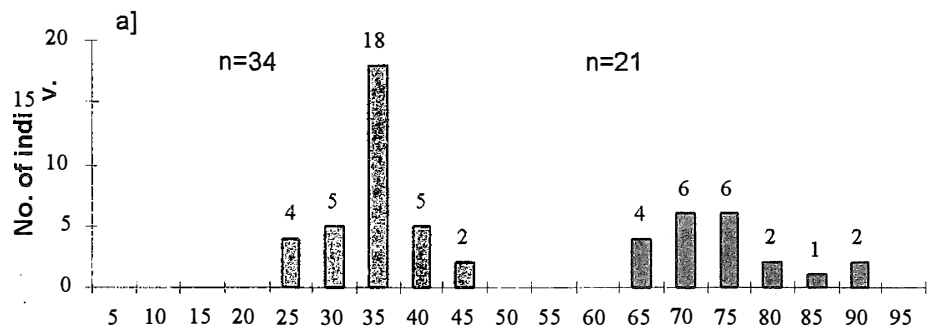

Edge increment [mm]

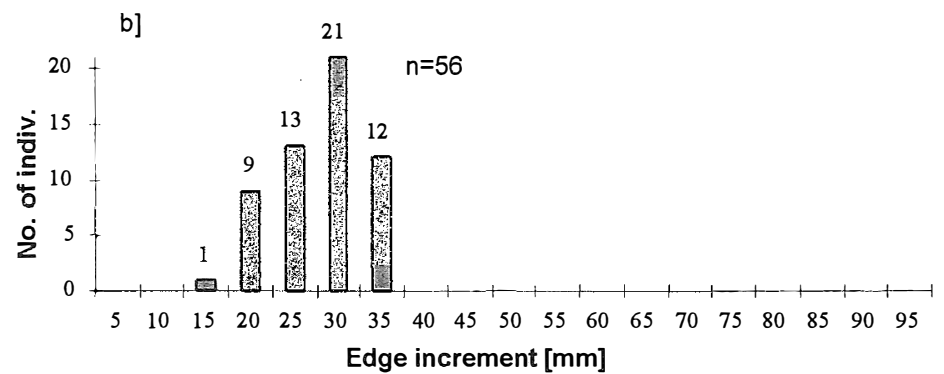

Fig. 7. Distribution of the edge increments of the smolts of the brown trout acquired in the season of 1982 in age groups $1+[\mathrm{a}]$ and $2+[\mathrm{b}]$
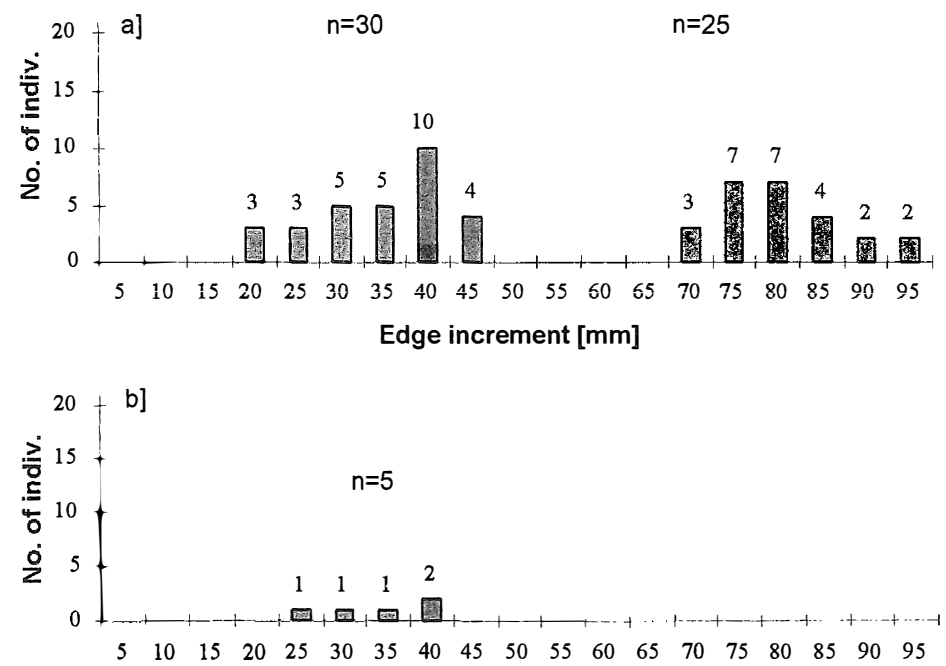

Edge increment [mm]

Fig. 8. Distribution of the edge increments of the smolts of the brown trout acquired in the season of 1983 in age groups $1+[\mathrm{a}]$ and $2+[\mathrm{b}]$ 


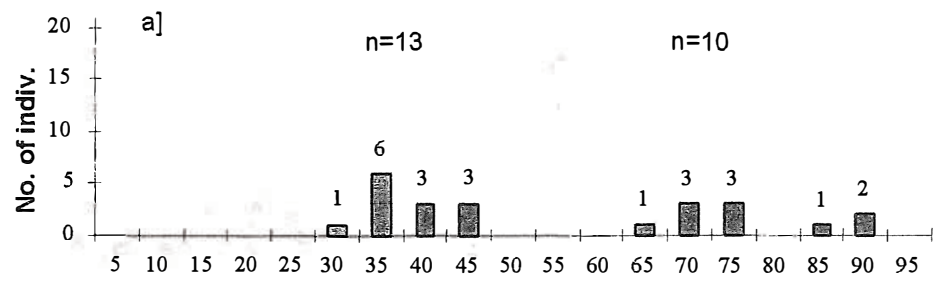

Edge increment [mm]

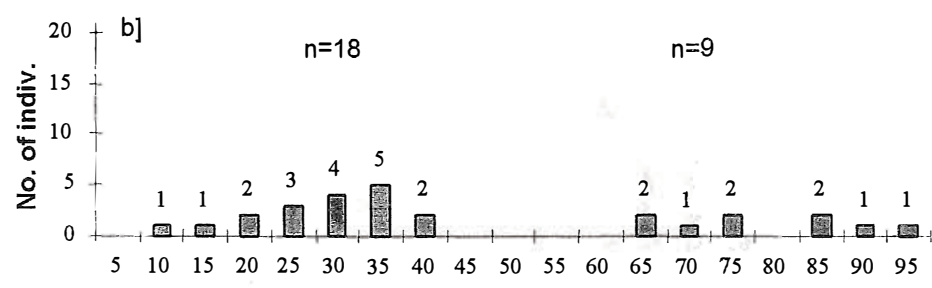

Edge increment [mm]

Fig. 9. Distribution of the edge increments of the smolts of the brown trout acquired in the season of 1984 in age groups $1+[\mathrm{a}]$ and $2+[\mathrm{b}]$

In the fishing season of 1982 there were 55 smolts representing group 1+. In this number there were 34 fish (61.8\%) with "small"- and 21 (38.2\%) with "big" edge increment (Fig. 7a). In the above-mentioned fishing season there were 56 smolts representing group $2+$ with "small" edge increment.

In the fishing season of 1983 there were 55 smolts assigned to group 1+. In this number there were 30 fish (54.5\%) with "small" = and $25(45.5 \%)$ with "big" edge increment (Fig. 8a). In the same fishing season there were only 5 smolts (Fig. 8b) representing group $2+$ with "small" edge increment.

Among 23 smolts of group 1+ acquired in the fishing season of 1984 there were 13 fish (56 5\%) with "small"- and 10 (43.5\%) with "big" edge increment (Fig. 9a). In the fishing season of 1984 there were 27 smolts representing group 2+. In this number were 18 fish (66.7\%) with "small"- and 9 fish (33.3\%) with "big" edge increment (Fig. 9b).

Summing up-in the whole material studied, in group 1+ there were 108 smolts with "small" edge increment, while only 69 fish with "big" edge increment. On the other hand in group $2+$ there were 87 smolts with "small" edge increment and 13-with big edge increment. 
The ranges of the edge increments and statistical calculations for mean length and weight of the smolts for the listed above fishing seasons and age groups, as well as for entire study is shown in Tab. 2 :

The variance analysis tests conducted for mean values of the length and weight of smolts in consecutive fishing seasons and for consecutive age-groups demonstrated that in group 1+ with "small" edge increment there were no significant differences as for the length and weight of the fish. In group 1+ with "big" edge increment there were also no significant differences as for the length of the fish, however, there were statistical differences in the fish weight. It was probably the result of different trophic conditions occurring in the Gowienica in the consecutive seasons. It can be assumed with high probability, which is confirmed by the tests presented in the next analysis, that it was caused by the wide range in the numbers of respective samples/seasons. (For example in 1982 there were 56 fish studied, while in 1984-only 5.)

It is evident form the scale structure, that the terminal sclerites of the groups $1+$ and $2+$ with "small" edge increment are wider, than the sclerites ending the annual increment. Consequently they can be assumed as the sclerites of the new annual ring being formed. On the other hand the sclerites of groups $1+$ and 2+ with "big" edge increment become more narrow or keep constant width. Wide edge increment indicates an ending annual increment. The former type of scales occurs more often than the latter type (55.8-44.2\%).

The conducted tests of variance analysis of means of the smolts of group $1+$ with "big" edge increment and $2+$ with "small" edge increment demonstrated lack of significant differences in the length and weight. Both groups of smolts represent consequently fish of the real age of two years. The mean length of smolts in both joint groups was $172.0 \mathrm{~mm}$ (range 145.0-220.0 mm) and the weight-46.1 g (range 27.7-86.0 g) (Tab. 3).

The conducted tests of variance analysis of means for length and weight of smolts in individual seasons for this age group exhibited lack of significant differences in the length between the seasons. Significant differences were observed, however, in the weight of the fish, which can be explained by different trophic conditions throughout the seasons.

The above-mentioned tests give evidence, that a reason for significant differences in fish length in consecutive seasons in the previous analysis was the extensive range in the numbers of individual samples. 
Edge increments of the brown trout smolts in individual seasons. Lengths and weights of the fish studied

\begin{tabular}{|c|c|c|c|c|c|c|c|c|c|c|c|}
\hline \multirow{2}{*}{ Age } & \multirow{2}{*}{ Season } & \multirow{2}{*}{$\begin{array}{l}\text { Edge increment } \\
\text { range [mm] }\end{array}$} & \multirow{2}{*}{$\mathrm{n}$} & \multicolumn{4}{|c|}{ Length $[\mathrm{mm}]$} & \multicolumn{4}{|c|}{ Weight $[\mathrm{g}]$} \\
\hline & & & & $\bar{x} \pm \mathrm{m}$ & $\delta$ & $\mathrm{V}$ & Range & $\bar{x} \pm \mathrm{m}$ & $\delta$ & $\mathrm{V}$ & Range \\
\hline \multirow{5}{*}{$1+$} & 1980 & $21-44$ & 31 & $142.3 \pm 1.80$ & 10.03 & 7.05 & $124.0-160.0$ & $28.0 \pm 1.17$ & 6.54 & 23.31 & $16.8-38.4$ \\
\hline & 1982 & $20-43$ & 34 & $154.5 \pm 1.14$ & 6.67 & 4.32 & $128.0-162.0$ & $34.5 \pm 0.71$ & 4.15 & 12.01 & $18.9-41.0$ \\
\hline & 1983 & $16-44$ & 30 & $146.5 \pm 1.54$ & 8.42 & 5.75 & $130.0-160.0$ & $28.3 \pm 0.94$ & 5.14 & 18.18 & $18.9-38.7$ \\
\hline & 1984 & $32-36$ & 13 & $156.5 \pm 2.49$ & 8.99 & 5.74 & $145.0-175.0$ & $33.9 \pm 0.81$ & 2.91 & 8.59 & $28.2-38.3$ \\
\hline & Total & $16-44$ & 108 & $149.0 \pm 0.96$ & 10.02 & 6.73 & $124.0-175.0$ & $30.9 \pm 0.57$ & 5.89 & 19.09 & $16.8-41.0$ \\
\hline \multirow{5}{*}{$1+$} & 1980 & $63-87$ & 13 & $162.1 \pm 2.62$ & 9.44 & 5.82 & $152.0-178.0$ & $43.7 \pm 2.08$ & 7.51 & 17.18 & $32.0-58.0$ \\
\hline & 1982 & $57-89$ & 21 & $165.8 \pm 2.96$ & 13.56 & 8.18 & $150.0-198.0$ & $41.0 \pm 1.53$ & 7.01 & 17.08 & $27.7-56.1$ \\
\hline & 1983 & $65-90$ & 25 & $167.8 \pm 2.24$ & 11.19 & 6.67 & $150.0-190.0$ & $42.9 \pm 1.81$ & 9.05 & 21.11 & $31.4-67.4$ \\
\hline & 1984 & $61-87$ & 10 & $177.0 \pm 2.00$ & 6.32 & 3.57 & $165.0-185.0$ & $48.9 \pm 2.05$ & 6.49 & 13.29 & $41.0-63.5$ \\
\hline & Total & $57-90$ & 69 & $167.4 \pm 1.41$ & 11.71 & 6.99 & $150.0-198.0$ & $43.3 \pm 0.96$ & 8.01 & 18.48 & $27.7-67.4$ \\
\hline \multirow{5}{*}{$2+$} & 1980 & $17-39$ & 8 & $175.1 \pm 4.75$ & 13.43 & 7.67 & $154.0-192.0$ & $55.4 \pm 4.36$ & 12.33 & 22.25 & $39.5-76.8$ \\
\hline & 1982 & $13-34$ & 56 & $174.5 \pm 1.71$ & 12.77 & 7.32 & $150.0-220.0$ & $46.6 \pm 1.44$ & 10.77 & 23.13 & $31.8-86.0$ \\
\hline & 1983 & $23-38$ & 5 & $180.0 \pm 1.58$ & 3.54 & 1.96 & $175.0-180.0$ & $49.2 \pm 1.81$ & 4.04 & 8.21 & $42.4-52.6$ \\
\hline & 1984 & $9-36$ & 18 & $177.8 \pm 3.69$ & 15.65 & 8.80 & $145.0-205.0$ & $50.2 \pm 2.80$ & 11.88 & 23.65 & $31.0-68.0$ \\
\hline & Total & $9-39$ & 87 & $175.6 \pm 1.39$ & 13.00 & 7.40 & $145.0-220.0$ & $48.3 \pm 1.18$ & 11.01 & 22.80 & $31.0-86.0$ \\
\hline \multirow{3}{*}{$2+$} & 1980 & $67-82$ & 4 & $220.7 \pm 4.13$ & 8.26 & 3.74 & $215.0-233.0$ & $102.4 \pm 7.34$ & 14.69 & 14.34 & $90.0-118.7$ \\
\hline & 1984 & $61-94$ & 9 & $243.9 \pm 7.90$ & 23.69 & 9.71 & $215.0-285.0$ & $122.0 \pm 10.49$ & 31.48 & 25.80 & $81.0-167.0$ \\
\hline & Total & 61-94 & 13 & $236.8 \pm 6.29$ & 22.69 & 9.58 & $215.0-285.0$ & $116.0 \pm 7.86$ & 28.35 & 24.44 & $81.0-167.0$ \\
\hline \multicolumn{2}{|c|}{ Grand total } & - & 277 & $166.0 \pm 1.38$ & 22.91 & 13.80 & $124.0-285.0$ & $43.0 \pm 1.23$ & 20.46 & 47.60 & $17.0-167.0$ \\
\hline
\end{tabular}

$\mathrm{n}$-number; $\bar{x}$--arithmetic mean; $\mathrm{m}$-standard error; $\delta$-standard deviation; $\mathrm{V}$-variability coefficient;

The above abbreviations refer also to the next tables 
Table 3

Characteristics of the lengths and weights of the smolts of the brown trout of the Gowienica River in individual seasons (real age 2 years)

\begin{tabular}{|c|c|c|c|c|c|c|c|c|c|}
\hline \multirow{2}{*}{ Season } & \multirow{2}{*}{$\mathrm{n}$} & \multicolumn{4}{|c|}{ Length [mm] } & \multicolumn{4}{c|}{ Weight [g] } \\
\cline { 3 - 10 } & & $\bar{x} \pm \mathrm{m}$ & \multicolumn{1}{|c|}{$\delta$} & $\mathrm{V}$ & Range & $\bar{x} \pm \mathrm{m}$ & \multicolumn{1}{|c|}{$\delta$} & $\mathrm{V}$ & Range \\
\hline 1980 & 21 & $167.0 \pm 2.75$ & 12.60 & 7.54 & $152-192$ & $48.2 \pm 2.40$ & 10.99 & 22.81 & $32.0-76.8$ \\
1982 & 77 & $172.1 \pm 1.53$ & 13.40 & 7.78 & $150-220$ & $45.0 \pm 1.16$ & 10.08 & 22.38 & $27.7-86.0$ \\
1983 & 30 & $169.8 \pm 2.06$ & 11.26 & 6.63 & $150-190$ & $43.9 \pm 1.59$ & 8.71 & 19.81 & $31.4-67.4$ \\
1984 & 28 & $177.5 \pm 2.45$ & 12.95 & 7.29 & $145-205$ & $49.7 \pm 1.92$ & 10.17 & 20.44 & $31.0-68.0$ \\
\hline Total & 156 & $172.0 \pm 1.05$ & 13.08 & 7.61 & $145-220$ & $46.1 \pm 0.81$ & 10.10 & 21.91 & $27.7-86.0$ \\
\hline
\end{tabular}

The analyzed material contained also smolts $2+$ with "big" edge increment. Because this group of smolts was acquired in spring, therefore the edge increment of these fish was formed in the previous season of growth, which reflected the whole-year growth. Therefore their real age was 3 years. These smolts attained the mean length of $236.8 \mathrm{~mm}$ (range 215.0-285.0 mm, and mean weight of $116.0 \mathrm{~g}$ (range $81.0-167.0 \mathrm{~g}$ ). Finally, the fish of group $1+$ with "dk" $\leq 44 \mathrm{~mm}$ were assigned to the real-age group of one year there. The fish of group 1+ with "dk" $\geq 57 \mathrm{~mm}$ and of group $2+$ with " $\mathrm{dk}$ " $\leq 39 \mathrm{~mm}$ were assigned to the real-age group of two years there. Three-year-old fish comprised fish of group $2+$ with "dk" $\geq 61 \mathrm{~mm}$.

The analysis of the results obtained enabled determination of the age-structure of the smolts studied in individual seasons and in the whole study period. In the material consisting

Table 4 of 277 smolts, 108 fish $(39.0 \%$ of the sample

Age structure of the smolts studied in individual study seasons

\begin{tabular}{|c|c|c|c|c|c|c|c|}
\hline \multirow{3}{*}{ Year } & \multicolumn{7}{|c|}{ Number of fish } \\
\cline { 2 - 8 } & Overall & \multicolumn{2}{|c|}{ 1-year-old } & 2-year-old & \multicolumn{2}{|c|}{ 3-year-old } \\
\cline { 3 - 8 } & & Number & $\%$ & Number & $\%$ & Number & $\%$ \\
\hline 1980 & 56 & 31 & 55.4 & 21 & 37.5 & 4 & 7.1 \\
1982 & 111 & 34 & 30.6 & 77 & 69.9 & 0 & - \\
1983 & 60 & 30 & 50.0 & 30 & 50.0 & 0 & - \\
1984 & 50 & 13 & 26.0 & 28 & 56.0 & 9 & 18.0 \\
\hline Total & 277 & 108 & 39.0 & 156 & 56.3 & 13 & 4.7 \\
\hline
\end{tabular}
studied) were assigned to the group of one-year-old trout, while 156 fish $(56.3 \%)$ - to the group of two-year-olds, and 13 fish (4.7\%) - to three-year-old group (Tab. 4).

It is evident that the most abundant were two-

year-old fish, followed by one-year-old group, while three-year-old were least abundant. The domination of two-year-old smolts occurred also in the seasons of $1982(69.9 \%)$ and $1984(56.0 \%)$. On the other hand in the season of 1980, one-year-old smolts were the most abundant $(55.4 \%)$. In the season of 1983 one-year-old and two-year-old smolts were simi- 
larly abundant (50\%). Three-year-old smolts occurred in only two seasons studied: 1980 and 1984. In the latter year they were relatively abundant (18.0\%) (Tab. 4).

Out of the total of 287 smolts subjected to the age analysis, sex was determined in 162 fish (58.5\%). In six cases the age was not determined because of undetermined annual ring. Consequently the material studied was limited to 156 specimens.

It turned out, that among the fish studied, there were more females-81 (compared to 75 males). In the groups of one-year-old and three-year-old smolts also females were more abundant, while among two-year-olds there were more males (Tab. 5).

Table 5

Length and weight of male and female smolts from Gowienica in sequential years of life

\begin{tabular}{|c|l|r|c|r|r|c|c|c|}
\hline Real & \multirow{2}{*}{ Sex } & \multirow{2}{*}{$\mathrm{n}$} & \multicolumn{3}{|c|}{ Length [mm] } & \multicolumn{3}{c|}{ Weight [g] } \\
\cline { 4 - 9 } & & & $\bar{x} \pm \mathrm{m}$ & \multicolumn{1}{c|}{$\delta$} & $\mathrm{V}$ & $\bar{x} \pm \mathrm{m}$ & \multicolumn{1}{c|}{$\delta$} & $\mathrm{V}$ \\
\hline \multirow{3}{*}{1} & Females & 40 & $144.4 \pm 1.46$ & 9.25 & 6.41 & $27.8 \pm 0.81$ & 5.10 & 18.30 \\
& Males & 32 & $146.9 \pm 1.79$ & 10.15 & 6.91 & $29.9 \pm 1.12$ & 6.32 & 21.13 \\
& Total & $\mathbf{7 2}$ & $\mathbf{1 4 5 . 5} \pm \mathbf{1 . 1 3}$ & $\mathbf{9 . 6 1}$ & $\mathbf{6 . 6 0}$ & $\mathbf{2 8 . 8} \pm \mathbf{0 . 6 7}$ & $\mathbf{5 . 6 9}$ & $\mathbf{1 9 . 7 7}$ \\
\hline \multirow{3}{*}{2} & Females & 38 & $171.1 \pm 2.14$ & 13.18 & 7.70 & $45.4 \pm 1.54$ & 9.49 & 20.89 \\
& Males & 40 & $172.1 \pm 2.07$ & 13.10 & 7.61 & $45.8 \pm 1.73$ & 10.94 & 23.89 \\
& Total & $\mathbf{7 8}$ & $\mathbf{1 7 1 . 6} \pm \mathbf{1 . 4 7}$ & $\mathbf{1 2 . 9 8}$ & $\mathbf{7 . 5 6}$ & $\mathbf{4 5 . 6} \pm 1.15$ & $\mathbf{1 0 . 1 3}$ & $\mathbf{2 2 . 2 1}$ \\
\hline \multirow{3}{*}{3} & Females & 3 & $225.7 \pm 9.68$ & 16.77 & 7.43 & $100.8 \pm 15.19$ & 26.32 & 26.11 \\
& Males & 3 & $222.0 \pm 5.57$ & 9.64 & 4.34 & $106.6 \pm 8.58$ & 14.85 & 13.94 \\
& Total & $\mathbf{6}$ & $\mathbf{2 2 3 . 8} \pm \mathbf{5 . 0 6}$ & $\mathbf{1 2 . 4 0}$ & $\mathbf{5 . 5 4}$ & $\mathbf{1 0 3 . 7} \pm 7.91$ & $\mathbf{1 9 . 3 7}$ & $\mathbf{1 8 . 6 8}$ \\
\hline \multirow{3}{*}{ Total } & Females & 81 & $159.9 \pm 2.40$ & 21.57 & 13.49 & $38.8 \pm 1.90$ & 17.12 & 44.12 \\
& Males & $\mathbf{7 5}$ & $163.3 \pm 2.39$ & 20.68 & 12.66 & $41.5 \pm 2.07$ & 17.92 & 43.23 \\
& Total & $\mathbf{1 5 6}$ & $\mathbf{1 6 1 . 6} \pm \mathbf{1 . 7 0}$ & $\mathbf{2 1 . 2 2}$ & $\mathbf{1 3 . 1 3}$ & $\mathbf{4 0 . 1} \pm \mathbf{1 . 4 1}$ & $\mathbf{1 7 . 5 6}$ & $\mathbf{4 3 . 8 1}$ \\
\hline
\end{tabular}

The present material yielded mean values of length and weight of the studied smolts of the trout in sequential years of life, for both sexes separately (Tab. 5). Variance analysis tests conducted for each sex separately demonstrated significant differences between females and males in the respect of the length and weight. The differences were evident for individual age groups as well as for all fish combined. The males had slightly higher length and weight than the females, in the entire study period as well as in the consecutive years of life. The exception were three-year-old females which were longer than males.

\section{DISCUSSION}

According to Chełkowski (1978), Chelkowski and Chełkowska (1982), determination of the real age of smolts requires counting of the annual rings on the scales and analysis of the edge increments " $\mathrm{dk}$ ". In the course of the present study a similar analysis of the scales was performed involving the distribution of the edge increments. The presently studied material did not contain smolts of the age group 0+, similarly as in the material of Chełkowski 
(1978) and Chełkowski and Chełkowska (1982). On the other hand smolts $1+$ and $2+$ occurred in both materials. There were no $3+$ smolts. Neither in the present material $3+$ smolts were observed. It must be emphasized however, that $3+$ group was not numerous in those studies. It is evident form the cited works and based on the present material that the values of "dk" in the same age-groups are similar which is shown in Tab. 6. In the studies of Chełkowski (1978) and Chelkowska (1982) "small" edge increment in age groups ranged within 25-31 and 14-51 mm, while in the present study it was 16-44 mm. Similar values of "big" edge increments are attained by the smolts of the same age group $(1+)$. It is evident from the data of the aforementioned authors that it assumes values within 80-125 and 58-98 $\mathrm{mm}$ while the present results were $57-90 \mathrm{~mm}$. On the other hand, the values of age group 2+ with "small" edge increment were presently 9-39 $\mathrm{mm}$ and they differ from the data of the above authors, which were 9-29 $\mathrm{mm}$. The present results of the same group but with "big" edge increment differ as well. It is evident from the study of Chełkowski (1978) and Chelkowski and Chelkowska (1982) that it was within the range of 43-65 mm, while the results of the present study were $61-94 \mathrm{~mm}$.

Table 6

Comparison of ranges of the edge increments [mm] in age groups according to different authors

\begin{tabular}{|c|c|c|c|c|}
\hline \multicolumn{4}{|c|}{ Ranges of edge increment } & \multirow{3}{*}{ Author } \\
\hline 1 year & & & 3 years & \\
\hline $1+$ & $1+$ & $2+$ & $2+$ & \\
\hline $25-31$ & $80-125$ & $10-25$ & $43-65$ & Chełkowski (1978)_-Rega River \\
\hline $14-51$ & $58-98$ & $10-29$ & $45-65$ & $\begin{array}{l}\text { Chełkowski and Chełkowska (1982)- } \\
\text { Mołstowa River }\end{array}$ \\
\hline $16-44$ & $57-90$ & $9-39$ & $61-94$ & Present study \\
\hline
\end{tabular}

It turned out that the pattern of outer sclerites of the scales assumes similar shape in the present study as well as in the materials described by Chełkowski (1978) and Chełkowski and Chelkowska (1982). The sclerites of the smolt scales with "small" edge increments in age groups $1+, 2+$ are far away from each other. On the other hand, in the same age groups but with "big" edge increment terminal sclerites of the scales show small distances what is not always distinctly marked.

The above results confirm the idea of determining the real age of the trout smolts based on the analysis of the distribution of fish lengths represented by the respective values of the edge increment in individual age groups.

As determined from four-year-long present study one-year-old smolts constituted $39.0 \%$, two-year-old - $56.3 \%$, and three-year-old--4.7\% (Tab. 7). In individual fishing seasons the age structure of the studied smolts from the Gowienica River was variable. Two- 
year-old smolts were the most abundant in two seasons (1982 and 1984). In the season of 1980 dominated one-year-old smolts (55.4\%). In the season of 1983 , however, one-and two-year-old smolts were equally abundant (50\%). Three-year-old smolts occurred in two seasons only-1980 and 1984. Comparing the above data with the results of the other authors (Tab. 7) it is evident that the age structure of the smolts studied in the entire study period is very similar to the results obtained by Chelkowski (1978) for the Rega River. On the other hand, the age structure of the Gowienica smolts for the entire study period is distinctly different from the age structure of the smolts from the Osówka River (Chełkowski 1992; 1995) and from the Gnilna River (Dębowski and Radtke 1994). The age structure of the smolts from the Mołstowa (Chełkowski and Chełkowska 1982) is the most similar to the structure of the season of 1980 of the present study (Tab. 4).

It is interesting that in the age structure of the smolts from the Pomeranian rivers, determined from the scales of adult fish (broodstock) entering the rivers two-year-old smolts distinctly dominate, as confirmed by the authors cited in Tab. 7 .

One- and three-year-old smolts constituted a very low percentage in the age structure. It is not contradictory to the results of the present study, because one-year-old smolts incurred the highest mortality at sea (Chelkowski-personal communication). It may be important, that the authors studying the scales of adult fishes could have assumed "big" edge increment on the scales representing riverine life - as a full year of life.

The lengths of the smolts migrating down stream in individual age groups in the present study were very similar to the results of the other authors, pertaining to smolts of the Rega, Osówka, Mołstowa, and Gnilna (Tab. 8).

The average weight of one-year-old smolts of the present study fit in the ranges obtained by the other authors (Tab. 8). On the other hand the two-year-old smolts of the Osówka (Chełkowski 1995) differed the most in this respect from the remaining smolts of the Rega (Chełkowski 1978) and Mołstowa (36.6 g) (Chełkowski and Chełkowska 1982). The present study indicates that the average weight of the two-year-old smolts fits between the respective values of the smolt weight from both latter rivers. The weight values of the three-year-old smolts of the Rega River (Chelkowski 1978) and from the presently studied material are almost identical. The latter differ however from the values obtained for smolts of the Mołstowa River (Chełkowski and Chełkowska 1982) (Tab. 9). 
Age structure of the smolts from Pomeranian rivers

\begin{tabular}{|l|c|c|c|l|}
\hline \multirow{2}{*}{ River } & \multicolumn{3}{|c|}{ Smolts [\%] } & \multirow{2}{*}{ Author } \\
\cline { 2 - 4 } & 1-year-old & 2-year-old & 3-year-old & \\
\hline \multicolumn{5}{|c|}{ Determined from the smolt scales } \\
\hline Rega & 4.7 & 76.5 & 18.8 & Chełkowski (1978) \\
Osówka & 89.1 & 9.2 & 1.7 & Chełkowski (1992) \\
Osówka & 96.8 & 3.2 & - & Chełkowski (1995) \\
Mołstowa & 56.8 & 40.8 & 2.4 & Chełkowski and Chełkowska (1982) \\
Gnilna & 98.9 & 1.1 & - & Dębowski and Radtke (1994) \\
Gowienica & 39.0 & 56.3 & 4.7 & Present study \\
\hline \multicolumn{5}{|c|}{ Determined from scales of the adult fishes } \\
\hline Pomeranian Rivers & 15.0 & 77.0 & 8.0 & Chrzan (1959)* \\
Gowienica & 0.8 & 92.06 & 7.14 & Chełkowski (1967) \\
Shupia & 3.19 & 92.11 & 4.7 & Chełkowski (1969) \\
Grabowa & 3.08 & 92.30 & 4.62 & Chełkowski (1969) \\
Uniesta & 0.66 & 94.08 & 5.25 & Chełkowski (1969) \\
Parsęta & 2.17 & 91.16 & 6.67 & Chełkowski (1969) \\
Rega & 8.22 & 85.61 & 6.17 & Chełkowski (1969) \\
Rega & 13.19 & 78.97 & 7.84 & Chełkowski (1974) \\
Pomeranian Rivers & 3.41 & 86.77 & 9.82 & Domagała (1986) \\
\hline
\end{tabular}

* cited after Chełkowski (1978)

Table 8

List of mean values of length and weight of the brown trout smolts in their sequential years of life

\begin{tabular}{|c|c|c|c|c|c|c|}
\hline \multirow{2}{*}{$\begin{array}{l}\text { Real } \\
\text { age }\end{array}$} & \multirow{2}{*}{ River } & \multirow{2}{*}{$\mathrm{n}$} & \multicolumn{2}{|c|}{ Length [mm] } & \multicolumn{2}{|c|}{ Weight $[\mathrm{g}]$} \\
\hline & & & $\bar{x}$ & Range & $\bar{x}$ & Range \\
\hline \multirow{6}{*}{1 year } & $\operatorname{Rega}^{1}$ & 8 & 143.0 & $126.0-149.0$ & 30.0 & - \\
\hline & Osówka ${ }^{2}$ & 66 & 150.0 & $119.0-182.0$ & - & - \\
\hline & Osówka ${ }^{3}$ & 275 & 151.2 & $118.0-195.0$ & 38.2 & $16.3-84.5$ \\
\hline & Mołstowa ${ }^{4}$ & 142 & 132.1 & - & 22.5 & - \\
\hline & Gnilna $^{5}$ & 1270 & 144.4 & - & 30.7 & - \\
\hline & Gowienica (present study) & 108 & 149.0 & $124.0-175.0$ & 30.9 & $16.8-41.0$ \\
\hline \multirow{6}{*}{2 years } & $\operatorname{Rega}^{1}$ & 74 & 192.0 & $150.0-230.0$ & 75.0 & - \\
\hline & Osówka ${ }^{2}$ & 7 & 196.0 & $174.0-215.0$ & - & - \\
\hline & Osówka ${ }^{3}$ & 9 & 217.1 & $153.0-245.0$ & 118.1 & $35.0-171.8$ \\
\hline & Mołstowa $^{4}$ & 102 & 156.3 & - & 36.6 & - \\
\hline & Gnilna $^{5}$ & 14 & 182.8 & - & - & - \\
\hline & Gowienica (present study) & 156 & 172.0 & $145.0-220.0$ & 46.1 & $27.7-86.0$ \\
\hline \multirow{4}{*}{3 years } & $\operatorname{Rega}^{1}$ & 22 & 225.0 & $190.0-257.0$ & 117.0 & - \\
\hline & Osówka² & 2 & 253.0 & $245.0-260.0$ & - & - \\
\hline & Mołstowa $^{4}$ & 6 & 189.0 & - & 66.2 & - \\
\hline & Gowienica (present study) & 13 & 236.8 & $215.0-285.0$ & 116.0 & $81.0-167.0$ \\
\hline
\end{tabular}

${ }^{1}$ Chełkowski 1978; ${ }^{2}$ Chełkowski 1992; ${ }^{3}$ Chełkowski 1995; ${ }^{4}$ Chełkowski and Chełkowska 1982;

${ }^{5}$ Dębowski and Radtke 1994 
Comparison of length and weight of females and males of the smolts

\begin{tabular}{|l|l|c|c|c|c|}
\hline \multirow{2}{*}{ River } & \multicolumn{2}{|c|}{ Author } & \multicolumn{2}{c|}{ Length [mm] } & \multicolumn{2}{c|}{ Weight [g] } \\
\cline { 3 - 6 } & & Females & Males & Females & Males \\
\hline Mołstowa & Chełkowski and Chełkowska (1982) & 148.0 & 142.0 & 33.7 & 27.8 \\
Osówka & Chełkowski (1992) & 157.0 & 153.0 & 42.8 & 38.4 \\
Gowienica & Present study & 159.9 & 163.3 & 38.8 & 41.5 \\
\hline
\end{tabular}

Among the trout smolts migrating down-stream in the Gowienica River as well as in other Pomeranian rivers there were more females than males (Chelkowski 1992, 1995; Chełkowski and Chełkowska 1982). It was similar for the adult trout on their spawning migrations (Chełkowski and Domagała 1990). In the presently studied material the female $\mathrm{v}$. male ratio was $1: 0.9$. On the other hand in the broodstock of the trout in the Gowienica River (Chełkowski 1967) this ratio was like $1: 0.48$ (67.46-32.54\%) in favor of the females. Comparing the mean values of the length and weight of females and males of the smolts studied with the data of the other authors it can be concluded that the lengths and weights of the fish from different water courses are similar (Tab. 10).

Table 10

Comparison of the length and weight values of the females and males of the smolts in sequential years of life

\begin{tabular}{|c|l|l|c|c|c|c|}
\hline Real & River & \multicolumn{2}{|c|}{ Author } & \multicolumn{2}{c|}{ Length [mm] } & \multicolumn{2}{c|}{ Weight [g] } \\
\hline age & & & Females & Males & Females & Males \\
\hline \multirow{3}{*}{ 1 year } & Rega & Chełkowski and Chełkowska (1982) & 134.0 & 133.0 & 25.0 & 22.0 \\
& Osówka & Chełkowski (1992) & 150.0 & 148.0 & 34.0 & 33.0 \\
& Gowienica & Present study & 144.4 & 146.9 & 27.8 & 29.9 \\
\hline \multirow{3}{*}{ 2 years } & Rega & Chełkowski and Chełkowska (1982) & 158.0 & 155.0 & 39.0 & 35.0 \\
& Osówka & Chełkowski (1992) & 196.0 & 207.0 & 86.0 & 92.0 \\
& Gowienica & Present study & 171.1 & 172.1 & 45.4 & 45.8 \\
\hline \multirow{3}{*}{3 years } & Rega & Chełkowski and Chełkowska (1982) & 191.0 & 177.0 & 69.0 & 53.0 \\
& Osówka & Chełkowski (1992) & 253.0 & - & 195.0 & - \\
& Gowienica & Present study & 225.7 & 222.0 & 100.8 & 106.6 \\
\hline
\end{tabular}


terial in all three age groups males are longer and heavier. The only exception was the length of three-year-old females, which were longer than males (Tab. 10).

\section{CONCLUSIONS}

The present study on the biological characteristics of the trout smolts from the Gowienica River, based on the scale analysis allowed to draw the following conclusions:

1. The scales of the trout were in the period of annual ring formation. Some specimens had newly formed edge increment while the others did not have it yet.

2. The limit of the edge increments was $1+\leq 44 \mathrm{~mm}$ for the one-year-old smolts, $1+\geq 57$ $\mathrm{mm}$ for two-year-olds and $2+\geq 61 \mathrm{~mm}$ for the three-year-olds.

3. All one-year-old smolts had newly-formed edge increment. Out of two-year-old fish $44.2 \%$ had edge increment of the past year, while in the group of three-year-old smolts all specimens had the increment of the past year.

4. Riverine period of life of the smolts was between 1 and 3 years. The dominant age-group were the two-year-olds (56\%). The one-year smolts constituted $39.0 \%$ while the threeyear-old-only $4.7 \%$ of the studied samples.

5. The age structure of the studied smolts changed in consecutive seasons. In some years dominated two-year-old or one-year-old smolts. Sometimes their percentage was equal. The three-year-old smolts constituted a minority or were absent altogether.

6. The following mean values of the length and weight were achieved by the consecutive age groups of the smolts: one year: $\bar{x} \pm \mathrm{m}=149.0 \pm 0.96 \mathrm{~mm} ; 30.9 \pm 0.57 \mathrm{~g}$; two-years: $\bar{x} \pm \mathrm{m}=172.0 \pm 1.05 \mathrm{~mm} ; 46.1 \pm 0.81 \mathrm{~g}$; and three years: $\bar{x} \pm \mathrm{m}=236.8 \pm 6.29 \mathrm{~mm}$; $116.0 \pm 7.86 \mathrm{~g}$.

7. There were slightly more females than males $(1: 0.9)$

8. The males were longer and heavier than males in the entire study period as well as in the all age groups.

\section{REFERENCES}

Anonymous, 1949: Szczegółowy podział dorzecza Odry i rzek Przymorza [Detailed description of the Odra River drainage basin and the maritime rivers]. Pr. PIHM 90. (In Polish).

Backiel T., 1962: Determination of time annuals formation of fish scales. Acta Hydrobiol., 4: 393411.

Bartel R., Z. Zieliński, 1977-1983: Sprawozdanie z serwisu informacyjnego gospodarki łososiowej [Report of the information service of the salmonid fishes management]. IRŚ Olsztyn. (In Polish).

Chelkowski Z., 1966: Introdukcja troci do rzeki Gowienicy [Introduction of the brown trout to the Gowienica River]. Gosp. Ryb., 1: 18-19. (In Polish). 
Chelkowski Z., 1967: Troć (Salmo trutta morpha trutta L.) rzeki Gowienicy [Brown trout (Salmo trutta morpha fario L. of the Gowienica River]. Przegl. Zool., 11: 294-306. (In Polish).

Chelkowski Z., 1969: Pogłowie troci (Salmo trutta morpha trutta L.) rzek przymorskich Pomorza [The size of the brown trout population (Salmo trutta morpha fario L.) from the maritime rivers of Pomerania]. Przegl. Zool., 13: 72-91. (In Polish).

Chelkowski Z., 1974: Studia nad biologią troci (Salmo trutta L.) rzeki Regi [Studies on biology of the brown trout (Salmo trutta L.) of the Rega River]. DSc Thesis, Zesz. Nauk. AR Szczecin, ser. Rozprawy, 37. (In Polish).

Chelkowski Z., 1978: Studies on trout (Salmo trutta L.) wild smolts of the river Rega. Acta Ichth. Piscat., 8, 2: 41-58.

Chelkowski Z., 1992: Biological characteristics of sea trout (Salmo trutta L.) smolts of know age from Osówka stream. Acta Ichth. Piscat., 22, 2: 107-122.

Chelkowski Z., 1995: Biological characteristics of sea trout smolts (Salmo trutta m. trutta L.) grown from fry released in the stream Osówka. Acta Ichth. Piscat., 25, 1: 19-33.

Chelkowski Z ., B. Chelkowska, 1981: Descent of trout (Salmo trutta L.) smolts grown in river Mołstowa catchment area. Acta Ichth. Piscat., 11, 2: 57-65.

Chelkowski Z., B. Chelkowska. 1982: Biological characteristics of trout (Salmo trutta L.) smolts grown in river Mołstowa catchment area. Acta Ichth. Piscat., 12, 1: 57-68.

Chelkowski Z., B. Chelkowska. 1995: Biological characteristics of sea trout smolts (Salmo trutta m. trutta L.) grown in river Gowienica catchment area. Acta Ichth. Piscat., 25, 1: 35-47.

Chelkowski Z., B. Chelkowska, M. Ciupiński, 1994: Period of downstream migration of sea trout (Salmo trutta L.) smolts grown in Gowienica river. Acta Ichth. Piscat., 24, 1: 145-152.

Chelkowski $\mathbb{Z}$., J. Domagala, 1990: Stosunek płci u troci (Salmo trutta L.) rzek Pomorza w różnych fazach życia [Sex ratio in different stages of life of brown trout (Salmo trutta L.) of the Pomeranian rivers]. Rocz. Nauk. AR Wroc. Zoot. 34 (200): 25-30. (In Polish).

Chrzan F., 1959: Łosoś i troć w polskich połowach na Bałtyku w latach 1945-1955 [The Atlantic salmon and the brown trout in Polish catches on the Baltic within 1945-1955]. Prace MIR Ser. A, 10: 273-340 (cited after Chelkowski 1978). (In Polish).

Chrzan F., 1962: The scales of sea-trout of known age. Int. Counc. Explor. Sea, Salmon a Trout Comm., 25: 1-14.

Čugunova N.I., 1959: Rukovodstvo po izučenii vozrasta i rosta ryb [Age and the growth rate of the fishes]. Izd. AN SSSR, Moskva: 91-95. (In Russian).

Dahl K., 1910: The age growth of salmon and trout in Norway as shown by their scales. The Salmon ad Trout Association, 1: 1-144.

Dębowski P., G. Radtke, 1994: Spływ i charakterystyka smoltów troci (Salmo trutta m. trutta L.) w rzece Gnilnej (Pomorze) [Descent of the brown trout smolts (Salmo trutta m. trutta L.) and their characteristics in the Gnilna River (Pomerania)]. Rocz. Nauk. PZW, 7: 39-50. (In Polish).

Domagala J., 1986: Oogeneza troci (Salmo trutta L.) z rzek Pomorza Zachodniego na tle wzrostu, ze szczególnym uwzględnieniem zależności smolt - ryba dorosła [Oogenesis of the brown trout (Salmo trutta L.) from the Pomeranian rivers in relation to its growth with particular consideration of the relationship between the smolt and the adult fish]. DSc Thesis, Zesz. Nauk. AR Szczecin, ser. Rozprawy, 108. (In Polish).

Grudniewski C., 1961: Rozwój niektórych morfologicznych cech okresu larwalnego troci jeziorowej (Salmo trutta morpha lacustris L.) z jeziora Wdzydze [Development of some morphological features of the larval period in the landlocked morphotype of the brown trout (Salmo trutta morpha lacustris) from Wdzydze Lake]. Rocz. Nauk Rol., Ser. D 93: 595-626. (In Polish).

Greń J., 1984: Statystyka matematyczna. Metoda i zadania [Mathematical statistics. Method and exercises]. PWN, Warszawa. (In Polish).

Jokiel J., 1958: Losoś (Salmo salar) rzeki Wisły [Salmon (Salmo salar) of the Vistula River]. Rocz. Nauk Roln. Ser. B 73, 2: 169-170. (In Polish). 
Lea $\mathbb{E} ., 1910$ : On the methods used in the herring-investigations. Cons. Perm., int. Expl. Mer. 53: 175.

Nall G.H., 1930: The life of the sea trout. Seeley, Service Co. Ltd, London.

Ombredane D., A. Richard, 1988: Determination of optimum scales sampling location for sea trout smolts (Salmo trutta L.). Colloq. Sur la Truite Commune, Boves (France) 319 supplement: 224-238.

Opuszyński K., 1979: Podstawy biologii ryb [Foundations of fish biology]. PWRiL, Warszawa: 185-186. (In Polish).

Sych R., 1967a: Interpretacja husek troci (Salmo trutta L.) z rzeki Wisły [Interpretation of the scales of brown trout (Salmo trutta L.) of the Vistula River]. Acta Hydrobiol., 9, 3-4: 231-280. (In Polish).

Sych R., 1967b: Ocena wiarygodności łuskowych oznaczeń wieku ryb na przykładzie troci (Salmo trutta L.) [Assessment of the reliability of the scale-based age determination method on the example of the brown trout (Salmo trutta L.)]. Rocz. Nauk Rol. Ser. H 90, 2: 281-303. (In Polish).

Sych R., 1971: Elementy teorii oznaczania wieku ryb według łusek. Problem wiarygodności [Foundations of the scale-based age determination method of fishes. Question of reliability]. Rocz. Nauk Rol. Ser. H 93, 1: 7-73. (In Polish).

Szypula J., 1988: Przewodnik do ćwiczeń z biologii ryb [Fish biology_lab manual]. AR, Szczecin. (In Polish). 


\section{Oskar ANTOSZEK}

\section{STRUKTURA WIEKU SMOLTÓW TROCI WEDROWNEJ (SALMO TRUTTA M. TRUTTA L.) Z RZEKI GOWIENICA}

\section{STRESZCZENIE}

Gowienica jest rzeką pomorską. Przecina ona równoleżnikowo środkową część Niziny Szczecińskiej i uchodzi do Zatoki Stepnickiej będącej częścią Zalewu Szczecińskiego.

W latach 1980-1984 pozyskano w niej żakiem skrzydłowym (w miejscowości Widzieńsko 12,6 km od ujścia), 2010 sztuk smoltów troci wędrownej (Salmo trutta m. trutta L.), z czego do badań pod względem wieku przeznaczono losowo 277 osobników, a płeć określono u 156 ryb.

Ponieważ łuski smoltów znajdowały się w okresie formowania pierścieni rocznych, określenie wieku smoltów poprzedzono liczeniem pierścieni rocznych i analizą przyrostów skrajnych. Niektóre osobniki charakteryzowały się nowo uformowanym przyrostem krawędziowym na łuskach, natomiast $\mathrm{u}$ innych jeszcze go nie stwierdzono. Granica przyrostów krawędziowych „dk” wyniosła dla smoltów: jednorocznych $z$ grupy $1+\leq 44 \mathrm{~mm}$, dla dwuletnich $\mathrm{z}$ grupy $1+\geq 57 \mathrm{~mm}$ a dla grupy $2+\leq 39 \mathrm{~m}$, natomiast dla smoltów trzyletnich $\mathrm{z}$ grupy $2+\geq 61 \mathrm{~mm}$.

Wszystkie smolty jednoroczne charakteryzowały się nowo założonym przyrostem krawędziowym. W grupie ryb dwulemich $44,2 \%$ miało przyrost krawędziowy ubiegłoroczny, natomiast w grupie smoltów trzyletnich wszystkie osobniki charakteryzowały się przyrostem ubiegłorocznym.

Okres życia rzecznego smoltów wyniósł od 1 do 3 lat, przy czym dominowały osobniki dwuletnie - 56,3\% natomiast jednoroczne stanowiły $39,0 \%$, a trzylemie tylko $4,7 \%$ ogółu badanej próby. Struktura wieku omawianych smoltów w kolejnych sezonach zmieniała się. W niektórych latach dominowały smolty dwuletnie, lub jednoroczne, a niekiedy udział ich był jednakowy, natomiast najmniej było smoltów trzyletnich lub w ogóle ich brakowało.

W kolejnych latach życia smolty osiagnęły następujące średnie wartości dhugości i masy: jednoroczne $\bar{x} \pm \mathrm{m}=149,0 \pm 0,96 \mathrm{~mm} ; 30,9 \pm 0,57 \mathrm{~g}$, dwuletnie $\bar{x} \pm \mathrm{m}=172,0 \pm 1,05 \mathrm{~mm}$; $46,1 \pm 0,81 \mathrm{~g}$ i trzylemie $\bar{x} \pm \mathrm{m}=236,8 \pm 6,29 \mathrm{~mm} ; 116,0 \pm 7,86 \mathrm{~g}$.

Wśród badanych smoltów stwierdzono nieco więcej samic, a stosunek samic do samców wyniósł $1: 0,9$. W materiale $\mathrm{z}$ całego okresu badań oraz we wszystkich grupach wieku samce, $\mathrm{w}$ stosunku do samic, uzyskały większą średnią długość i większą średnią masę. Wyjątkiem była długość trzyletnich samic; większa niż samców.

Received: 27 October 1998

Author's address:

Oskar Antoszek PhD

Department of Fisheries Management in Inland Waters

Agricultural University of Szczecin

Kazimierza Królewicza 4, 71-550 Szczecin, Poland 